\title{
Chronic toxicologic study of the ethanolic extract of the aerial parts of Jatropha gossypiifolia in rats
}

\author{
Saulo R. Mariz, ${ }^{* 1}$ Gilberto S. Cerqueira, ${ }^{2}$ Washington C. \\ Araújo, ${ }^{3}$ Jadson G. Dantas, ${ }^{3}$ Josué A. Ramalho, ${ }^{3}$ Thayse \\ V. Palomaro, ${ }^{3}$ José C. Duarte, ${ }^{3}$ Hosana B. dos Santos, ${ }^{2}$ \\ Kardilândia Olveira, ${ }^{2}$ Maria Salete T. de Araújo, ${ }^{2}$ Margareth \\ de F. F. M. Diniz, ${ }^{3}$ Isac A. de Medeiros ${ }^{3}$
}

${ }^{1}$ Centro de Ciências Biológicas e da Saúde, Universidade Federal de Campina Grande, Brazil,

${ }^{2}$ Hospital Universitário "Lauro Wanderley”, Universidade Federal da Paraíba, Brazil,

${ }^{3}$ Laboratório de Tecnologia Farmacêutica "Prof. Delby Medeiros", Universidade Federal da Paraíba, Brazil.

\begin{abstract}
This work presents the observed changes in Wistar rats under long treatment (thirteen weeks) with different oral doses of the ethanolic extract (EE) from Jatropha gossypiifolia L., Euphorbiaceae. The most significant toxic signs indicated a reduction of the activity in the central nervous system and digestive disturbances. The histopathological analysis shows hepatotoxity and pulmonary damages. The lethality was $46.6 \%$ among males under the higher experimental dose $(405 \mathrm{mg} / \mathrm{kg})$ and $13.3 \%$ both in females under the higher dose and among the animals treated with $135 \mathrm{mg} / \mathrm{kg}$ of the product. These data show the significant oral chronic toxicity of EE of J. gossypiifolia in rats.
\end{abstract}

Revista Brasileira de Farmacognosia Brazilian Journal of Pharmacognosy 22(3): 663-668, May/Jun. 2012

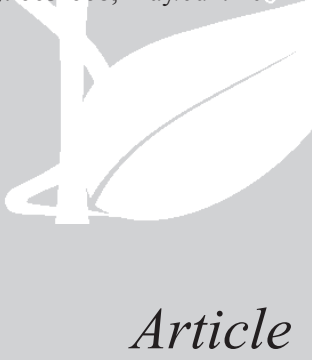

Article

Received 28 Feb 2011

Accepted 19 Dec 2011

Available online 3 Feb 2012

Keywords:

chronic toxicity

Euphorbiaceae

Jatropha gossypiifolia

ISSN 0102-695X

http://dx.doi.org/10.1590/S0102$695 \times 2012005000024$

\section{Introduction}

The research with medicinal plants aiming at the development of phytotherapeutic medicines and the promotion of the rational use of these products by the population of developing countries like Brazil, have a great importance not only in the socio-economic aspects but also because they enable a greater knowledge of the culture of such people and a better utilization of the biodiversity of the respective countries (Brandão et al., 2006).

However, it is necessary that the approaches in this area be multidisciplinary with studies that emphasize not only the evaluation of the therapeutic efficiency of traditional use, but also the safety such practices. When dealing with natural products like medicinal plants, usually used in natura, the studies for the evaluation of toxicity have their importance enhanced due to the fact that the chemical composition of such products is complex and diverse, something that may reduce still more the narrow threshold between the therapeutic and the toxic (Tomlinsom et al., 2000; Ernst \& Pittler, 2002; Chan et al., 2005).

The Jatropha gossypiifolia L., Euphorbiaceae, in spite of classified as toxic, has been very much used in popular medicine in the treatment of several diseases. The various chemical and pharmacological studies carried out with this species, including the demonstration of a significant hypotensive potential, have confirmed some of these traditional uses. However, some studies presenting signs of hepatic toxicity of the $J$. gossypiifolia have been published (Abreu et al., 2003; Kumar et al., 2006; Mariz et al., 2010).

In recent publications, we showed that the ethanolic extract of aerial parts (leaves and stem) of this species produced a relatively low oral acute toxicity in rats, though pointing out that the signs of hepatic, renal and pulmonary toxicity should be better evaluated through chronic toxicological studies (Mariz et al., 2006; Mariz et al., 2008).

Thus, this study aimed at evaluating the chronic toxicity of the ethanolic extract (EE) of J. gossypiifolia L., Euphorbiaceae, in rats so as to generate data that might allow an analysis of the risk/benefit relation of an eventual therapeutic use of this species. In this publication, we present both the results of parameters evaluated during the treatment and the indicators of toxicity analyzed after the treatment of Wistar rats with different doses of the ethanolic extract (EE) of aerial 
parts of J. gossypiifolia.

\section{Materials and methods}

Vegetal collection and preparation of ethanolic extract

The aerial parts (leaves and stems) of Jatropha gossypiifolia L., Euphorbiaceae, were collected in the municipality of Santa Rita, PB, Brazil, from June to August, 2004, and identified by "Lauro Pires" Herbarium at Paraíba Federal University, where a representative sample of the species registered under the code: Agra \& Góis 4192 (JPB). The ethanolic extract (EE) of $J$. gossypiifolia, the product evaluated in this study, was prepared according to the habitual methods. The yield of dried extract was $7.9 \%$ (w/w). Phytochemical study confirmed the presence of tannins, steroids and flavonoids.

\section{Animals}

Adult Wistar albino rats (Rattus norvegicus) were used, weighing between 250 and $350 \mathrm{~g}$ (males) and females (between 150 and $250 \mathrm{~g}$ ) were nulliparous and not pregnant. The animals were supplied by "Prof. Thomas George" Vivarium of "Prof. Delby Medeiros" Laboratory of Pharmaceutical Technology (LTF-UFPB), maintained under standard ambient conditions and fed with ration and potable water as much as they wanted. The experimental protocols were performed according to the international, national, and institutional rules considering animal experiments and biodiversity rights and were approved by the Ethics Committee in Animal Research (CEPA) at LTFUFPB through the certificate $\mathrm{N}^{\circ} 0105 / 06$.

\section{Toxicological tests}

The experimental protocols obeyed the current legislation (Anvisa, 2004). The animals were treated with oral doses of: 45,135 and $405 \mathrm{mg} / \mathrm{kg}$ of the ethanolic extract (EE) of aerial parts of the plant, during thirteen weeks ( $n=10$ per group). The animals of the control group were treated with water, the resuspension vehicle of the extract. In order to evaluate the reversibility of the of the effects, two satellite groups were made, one using the dose of $135 \mathrm{mg} / \mathrm{kg}$ and another using the dose of $405 \mathrm{mg} / \mathrm{kg}$ ( $\mathrm{n}=5$ per group), which were evaluated during thirty days after the end of treatment. It was observed daily: general toxic signs, by using the proposed methodology by Almeida et al (1999); weight evolution; water and food consumption and lethality. The body temperature and the caudal glycemia were evaluated each fifteen days alternately. It was also observed eventual behavioral changes through Open Field experiments and the motor activity through the Rota Rod test, carried out each fifteen days too and alternately.

After the treatment, $40 \%$ of the animals of group were put down by low pull. The blood collected from the thoracic cavity was packed in tubes for laboratory tests. Among the biochemical parameters these were measured: glucose, urea, creatinine, uric acid, total proteins, albumin, globulin, cholesterol, triacylglycerides, total bilirubin, transaminase (AST and ALT), alkaline phosphatase, amylase, gammaglutamil transpeptidase (gamma-GT), creatine phosphokinase, (CPK), lactatodesidrogenase (LDH), calcium and magnesium. The hematological evaluation was carried out through erythrogram, leucogram and platelets count.

The collection of viscera (liver, kidneys, heart and lungs) was carried out for the microscopic and histopathologic test according to habitual methods (Michalany, 1998).

\section{Statistic analysis}

The numeric results were expressed in arithmetic mean \pm SEM and submitted to appropriate statistic tests (ANOVA and Turkey) with the help of the GraphPad Prism 3.0 program. The results were considered statistically significant when $p<0.05$ (Gad \& Weil, 1989; Graphpad Prism, 1998).

\section{Results and Discussion}

The animals of the control group did not show considerable changes in the evaluated parameters and, in most cases, their organic parameters evaluated numerically were within the reference values for the animals of the vivarium obtained through previous standardization. The few exceptions to this fact only reinforce the importance of the use of parallel control groups in each experiment, having in mind that some indicators are sensitive to individual and/or seasonal variations, among others.

During the treatment one can see, in some animals from all treated groups, of both sexes and in intensity proportional to the dose, the following general signs of toxicity: piloerection; stereotyped behavior of self-grooming and discreet grouping. In the animals treated with $135 \mathrm{mg} / \mathrm{kg}$ and, more intensely, in those treated with $405 \mathrm{mg} / \mathrm{kg}$, besides the effects mentioned before, it was observed: prostration, abdominal contortions; increase in evacuation; dyspnea; moderate eyelid ptosis and hindlimb paralysis, a sign which is associated with gradual weight loss and starvation, were previous characteristics of death. These effects had already been reported previously during the acute exposition of rats to high doses of ethanolic extracts of $J$. gossypiifolia and seem to confirm the signs 
of reduction of CNS activity and gastrointestinal disturbances (Mariz et al., 2006).

As far as alterations in the weight evolution is concerned, the product seems to increase the weight gain in smaller doses and reduce it in larger doses, the males being more sensitive to weight loss than the females, so much so that the only group with significant impairment of weight evolution throughout the treatment was that of the males treated with the larger experimental dose (Figure 1).

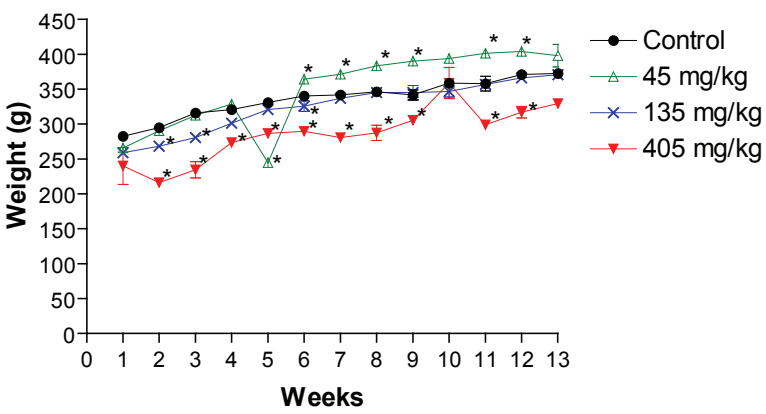

Figure 1. Weight evolution in males under prolonged treatment (13 weeks) with different doses (v.o.) of EE of Jatropha gossypiifolia L. *Values statistically different from the control group (ANOVA followed by Turkey, $p<0.05$ ); $\mathrm{n}=10$.

The consumption of food was by and large high and similar to weight evolution with smaller doses and reduced with higher doses, while the alterations in water ingestion were sporadic and diversified. It becomes clear that the changes in these parameters cannot be considered the only ones responsible for the changes in the weight evolution, considering that, during most part of the treatment, there was no correspondence between the alteration of gain and weight loss and those observed in the consumption of food and water. That is, other metabolic parameters must have been affected by the extract, mainly in males treated with the higher dose, where the significant weight loss corroborates the findings of the acute study (Mariz et al., 2006).

Thus, other indicators of the animal metabolism were evaluated. The body temperature was high in the beginning and reduced at the end of the treatment, in a way not proportional to the dose and in both sexes. However, such alterations did not present clinic significance, for they were sporadic and, most of times, they take place within the range of normality of this parameter in rats, which is from 37.5 to $38.5^{\circ} \mathrm{C}$.

In the behavioral study, in all the parameters observed, the only statistically significant alteration was a $68.5 \%$ reduction in relation to control, in the rearing of females treated with the dose of $405 \mathrm{mg} / \mathrm{kg}$, during the second experimental week. In the evaluation of the animals' motor activity, through the Rota Rod, the only relevant alteration was the reduction $(54.5 \%$ in relation to the control) of the time of permanence, of females $(405 \mathrm{mg} / \mathrm{kg})$ during the third experimental week (Figure 2). These results confirm the signs of activity reduction of CNS, including the decrease of locomotor function already reported during -the evaluation of the acute toxicity of the extract (Mariz et al., 2006).

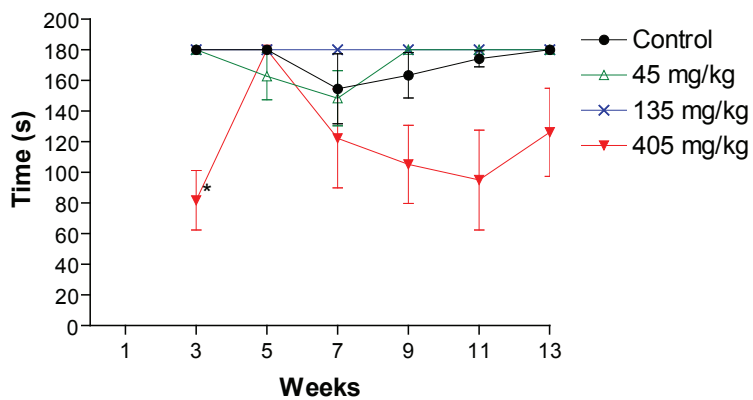

Figure 2. Rinding time (in seconds), in the Rota Rod, of female rats under prolonged treatment (13 weeks) with different doses of EE of Jatropha gossypiifolia L. The values express the mean \pm SEM of each group $(n=5)$. *Values statistically different from the control group (ANOVA followed by Turkey, $p<0.05$ )

A sign of hyperglycemic potential was also observed. In spite of the increases of caudal glycemia, during the treatment, having been sporadic and without clinic relevance, there was reversible hyperglycemia (absent in the satellite group) among males treated with a smaller dose $(45 \mathrm{mg} / \mathrm{kg})$ of $54 \%$ in relation to the range of reference $(76.0-98.0 \mathrm{mg} / \mathrm{dL})$ for the animals of the vivarium (Diniz, 2000), as shown in table 1. It is known that the mechanisms which control the glycemia levels are complex, and in some cases, only partially known. Anyway, the alterations in blood values of glucose must be understood initially as a sign of hepatic aggravation as this organ is a primary regulator of the glucose in the body (Kaneko, 1997).

Another isolated and reversible biochemical alteration was an increase of the total proteins among males treated with $405 \mathrm{mg} / \mathrm{kg}$ of the extract, something that can be considered discreet, as it overcame in $7.3 \%$ the reference for animals of the vivarium (Diniz, 2000). Considering that the greater part of the seric proteins has hepatic synthesis (Kaneko, 1997), this finding, although unspecific, also indicates a hepatotoxic potential of the extract (Table 1).

Table 1 also presents the hematologic parameters significantly modified by the treatment with the researched product. In the beginning, one notes a light and reversible anemia in males treated with $405 \mathrm{mg} / \mathrm{kg}$, in view of the reduction of the values of hemoglobin and hematocrit. The analysis of the hematimetric indexes proved that this anemia was that 
Table 1. Biochemical and hematologic parameters modified significantly in Wistar rats, by the prolonged treatment with different doses of the EE of the Jatropha gossypiifolia L.

\begin{tabular}{|c|c|c|c|c|c|}
\hline \multirow[b]{2}{*}{ Groups } & \multicolumn{4}{|c|}{ Biological parameters } & \multirow[b]{2}{*}{$\begin{array}{l}\text { Platelets } \\
\left(10^{6} / \mathrm{mm}^{3}\right)\end{array}$} \\
\hline & $\begin{array}{l}\text { Glycemia } \\
(\mathrm{mg} / \mathrm{dL})\end{array}$ & $\begin{array}{l}\text { Total Proteins } \\
\text { (g/dL) }\end{array}$ & $\begin{array}{l}\text { Hemoglobin } \\
(\mathrm{g} / \mathrm{dL})\end{array}$ & $\begin{array}{l}\text { Hematocrit } \\
(\%)\end{array}$ & \\
\hline \multicolumn{6}{|c|}{ Males } \\
\hline Reference $* *$ & $76.0-98.0$ & $5.1-6.8$ & $14.0-15.0$ & $39.0-43.0$ & $595.0-784.0$ \\
\hline Control & $110.6 \pm 4.1$ & $6.5 \pm 0.1$ & $14.7 \pm 0.4$ & $45.2 \pm 1.8$ & $728.0 \pm 23.2$ \\
\hline $45 \mathrm{mg} / \mathrm{kg}$ & $151 \pm 2.0^{*}$ & $6.6 \pm 0.1$ & $14.5 \pm 0.2$ & $42.0 \pm 1.1$ & $673.0 \pm 81.0$ \\
\hline $135 \mathrm{mg} / \mathrm{kg}$ & $126 \pm 12.6$ & $6.4 \pm 0.1$ & $13.9 \pm 0.2$ & $39.7 \pm 1.3$ & $749.6 \pm 91.0$ \\
\hline $405 \mathrm{mg} / \mathrm{kg}$ & $107 \pm 2.9$ & $7.3 \pm 0.0^{*}$ & $12.8 \pm 0.6^{*}$ & $36.2 \pm 2.0^{*}$ & $766.3 \pm 67.3$ \\
\hline Satellite (135 mg/kg) & $94.6 \pm 9.6$ & $7 \pm 0.1$ & $13.0 \pm 0.0$ & $39.9 \pm 0.1$ & $1.036 .5 \pm 17.3$ \\
\hline Satellite (405 mg/kg) & $126 \pm 9.8$ & $6.9 \pm 0.0$ & $14.1 \pm 0.2$ & $43.7 \pm 0.6$ & $915.5 \pm 39.3$ \\
\hline \multicolumn{6}{|c|}{ Females } \\
\hline Reference** & $78.0-100.0$ & $5.5-6.9$ & $12.0-15.0$ & $33.0-42.0$ & $494.0-784.0$ \\
\hline Control & $100.3 \pm 4.2$ & $6.9 \pm 0.3$ & $14.8 \pm 0.3$ & $43.7 \pm 1.1$ & $547.5 \pm 35.1$ \\
\hline $45 \mathrm{mg} / \mathrm{kg}$ & $129.3 \pm 9.4$ & $6.8 \pm 0.1$ & $14.3 \pm 0.1$ & $41.4 \pm 0.2$ & $722.3 \pm 94.4$ \\
\hline $135 \mathrm{mg} / \mathrm{kg}$ & $104.0 \pm 6.1$ & $7.0 \pm 0.0$ & $14.6 \pm 0.2$ & $41.0 \pm 0.6$ & $600.6 \pm 43.9$ \\
\hline $405 \mathrm{mg} / \mathrm{kg}$ & $106.0 \pm 3.8$ & $6.9 \pm 0.0$ & $13.5 \pm 0.3$ & $37.3 \pm 0.7$ & $850.3 \pm 25.9$ \\
\hline Satellite (135 mg/kg) & $93.6 \pm 4.0$ & $7.2 \pm 0.1$ & $14.5 \pm 0.5$ & $43.1 \pm 1.3$ & $1.061 .5 \pm 4.6^{*}$ \\
\hline Satellite $(405 \mathrm{mg} / \mathrm{kg})$ & $102.0 \pm 5.1$ & $7.5 \pm 0.1$ & $12.7 \pm 0.2$ & $38.1 \pm 0.7$ & $719.0 \pm 141.1$ \\
\hline
\end{tabular}

The values express the mean \pm SEM of each group $(\mathrm{n}=4) .{ }^{*} p<0.05$ (ANOVA followed by Turkey). **Values recommended by Diniz (2000).

of the macrocytic and hypercromic type. A late effect of increase in the plate of platelets (in satellite females treated with the dose of $135 \mathrm{mg} / \mathrm{kg}$ ) was observed. This lab finding may mean, among other situations, hemorrhages and splenic toxicity.

As far as anatomopathological findings are concerned, homogeneous and dark spots were observed, a sign of necrotizing action, in livers of males $(405 \mathrm{mg} /$ $\mathrm{kg}$ ) and in kidneys of satellite females treated with 135 $\mathrm{mg} / \mathrm{kg}$ of the extract. A fatty nodule was also found, a sign of steatosis, in livers of satellite males with dose of $405 \mathrm{mg} / \mathrm{kg}$. These data corroborate the indications of hepatotoxicity and renal toxicity discussed previously. As for the histopathological alterations, it was noted that in the liver and lungs of animals treated with the dose of $405 \mathrm{mg} / \mathrm{kg}$ there were aggressions towards these organs basically evidenced, through an inflammatory response and stimulation of the immunitary system.

Discreet chronic portite (Figure 3), and focuses of tubular necrosis were observed in the liver, besides light lobular fibrosis in zone 3, discreet venular congestion and hyperplasia kupfferian The lungs showed, mainly in males, extensive areas with congested capillaries and lymphocytic exudation causing septum thickening with restrictions of the corresponding alveolar spaces. This characterizes chronic intersticial pneumonitis, besides BALT hyperplasia. In the kidneys, the peripheric adipose tissue evidenced focal adiponecrosis (hystiocitic exudadation, with xanthomatous standard).

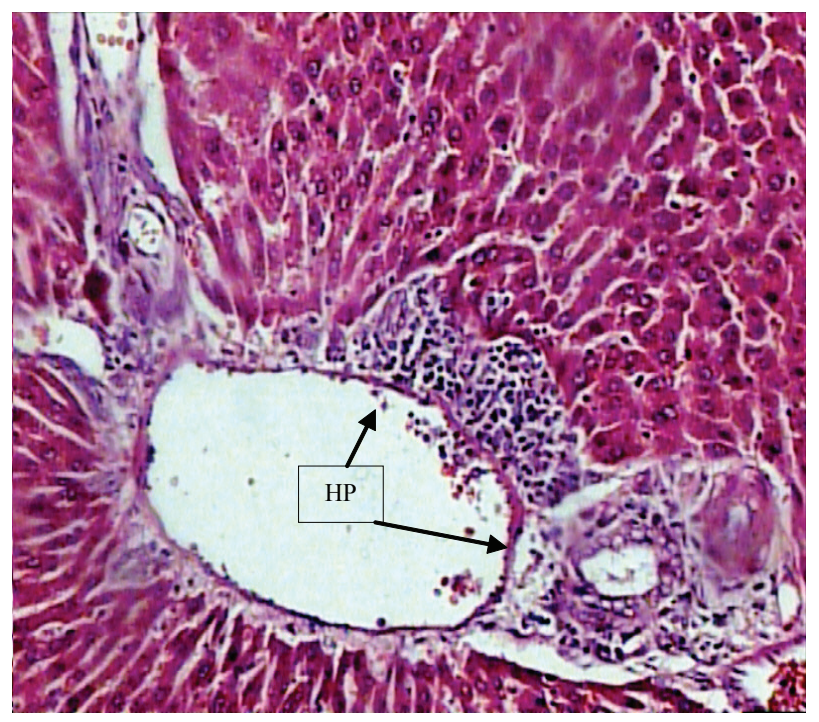

Figure 3. Hepatic Portite (HP)* in Wistar rats under prolonged treatment (13 weeks) with $405 \mathrm{mg} / \mathrm{kg}$ (v.o.) of EE of Jatropha gossypiifolia L. *(hematoxilineeosine - X100).

In spite of showing organic aggression which can be considered discreet and localized, this situation is very important for it tells us about the reproducibility 
of the histotoxic effects of the product in the hepatic and pulmonary tissues. This happens because the histologic alterations produced by the higher dose of the chronic study, were very similar to those observed during the acute poisoning from the dose of $5 \mathrm{~g} / \mathrm{kg}$ of the EE of $J$. gossypiifolia (Mariz et al., 2008). As previously discussed, these effects corroborate the signs of hepatotoxicity suggested by the evaluation of other parameters of this study, besides pointing to a potential of pulmonary toxicity also in the prolonged treatment with the EE of J. gossypiifolia L.

As far as the occurrence of deaths is concerned, the dose of $405 \mathrm{mg} / \mathrm{kg}$ produced a larger lethality in males $(46.6 \%)$ than in females $(13.3 \%)$. The lethality among animals treated with $135 \mathrm{mg} / \mathrm{kg}$ was $13.3 \%$ and the treatment with $45 \mathrm{mg} / \mathrm{kg}$ did not produce deaths (Table 2). These data inform about the seriousness of the risk to health with the prolonged exposition to the EE of Jatropha gossypiifolia, considering that deaths occur in the second experimental dose already (135 $\mathrm{mg} / \mathrm{kg}$ ). This dose corresponds to that in which it was demonstrated experimentally the hipotensor effect of the plant (Abreu et al., 2003), thus being the one that would be near therapeutics, in case the specie should be validated as phytotherapeutic drug. Still pointing out the seriousness of these data, one should consider that the larger experimental dose $(405 \mathrm{mg} / \mathrm{kg})$, which killed more than $46 \%$ of the males treated, is less than twice the larger hipotensor dose of the extract published by Abreu et al (2003).

Table 2. Lethality (\%) in rats under prolonged treatment with different doses of the EE of Jatropha gossypiifolia L.

\begin{tabular}{lcc}
\hline \multirow{2}{*}{ Groups (doses) } & \multicolumn{2}{c}{ Lethality (\%) } \\
\cline { 2 - 3 } & Males & Females \\
\hline Control & 0 & 0 \\
$45 \mathrm{mg} / \mathrm{kg}$ & 0 & 0 \\
$135 \mathrm{mg} / \mathrm{kg}$ & 13.3 & 13.3 \\
$405 \mathrm{mg} / \mathrm{kg}$ & 46.6 & 13.3 \\
\hline
\end{tabular}

\section{Conclusions}

The results of the evaluated indicators in this study inform that the extract presents signs of neurologic, gastrointestinal, hepatic and renal toxicity, already reported in the evaluation of acute toxicity, besides pulmonary damage. These data associated mainly with the high percentage of lethality in doses near eventual therapeutic levels, indicate a chronic oral toxicity in rats, which is significant for the ethanolic extract of aerial parts of Jatropha gossyiifolia L.

\section{Acknowledgements}

The authors thank the CAPES which, through the Program of Interinstitutional Qualification (PQI), financed this research.

\section{References}

Abreu IC, Marinho ASS, Paes AMA, Freire SMF, Olea RSG, Borges MOR, Borges ACR 2003. Hypotensive and vasorelaxant effects of the ethanolic extract from Jatropha gossypiifolia L. in rats. Fitoterapia 74: 651657.

Almeida RN, Falcão ACGM, Diniz RST, QuintansJúnior LJ, Polari RN, Barbosa-Filho JM, Agra MF, Duarte JC, Ferreira CD, Antoniolli AR, Araújo CC 1999. Metodologia para avaliação de plantas com atividade no Sistema Nervoso Central e alguns dados experimentais. Rev Bras Farm 80: 72-76.

Anvisa 2004. Agência Nacional de Vigilância Sanitária, Ministério da Saúde, Resolução RE n 90/2004. Normas para estudos toxicológicos de produtos fitoterápicos. Diário Oficial [da] República Federativa do Brasil, Poder Executivo, Brasília, DF, 12 de março de 2004.

Brandão MGL, Cosenza GP, Moreira RA, Monte-Mor RLM 2006. Medicinal plants and other botanical products from the Brazilian Official Pharmacopoeia. Rev Bras Farmacogn 16: 408-420.

Chan TYK, Tam HP, Lai CK, Chan AYW 2005. A multidisciplinary approach to the toxicologic problems associated with the use of herbal medicines. Ther Drug Monit 27: 53-57.

Diniz MFFM. Estudos de toxicidade pré-clínica de extratos de folhas de Cissampelos sympodialis Eich. 147 f. 2000. Tese (Doutorado em produtos naturais e sintéticos bioativos), Universidade Federal da Paraíba, João Pessoa.

Ernst E, Pittler MH 2002. Risks Associated with Herbal Medicinal Products. WMW.7: 183-189.

Gad SC, Weil CS 1989. Statistics for Toxicologists, in: Principles and Methods of Toxicology, Hayes AW (Ed.). Raven Press, New York, p. 435-483.

Graphpad Prism 1999. User's Guide Version 3.0: the fast, organized way to analyze and graph scientific data. San Diego. Disponível em: <http: www.graphpad. com>. Acessed 23 May 2008.

Kaneko JJ, Harvey JW, Bruss ML 1997. Clinical biochemistry of domestic animals. Academic Press, San Diego.

Kumar VP, Chauhan NS, Padh H, Rajani M 2006. Search for antibacterial and antifungal agents from selected Indian medicinal plants. J Ethnopharmacol 107: 182188.

Mariz SR, Araújo MST, Cerqueira GS, Araújo WC, Duarte JC, Diniz MFFM, Medeiros IA 2008. Avaliação 
histopatológica em ratos após tratamento agudo com o extrato etanólico de partes aéreas de Jatropha gossypiifolia L. Rev Bras Farmacogn 18: 213-216.

Mariz SR, Borges ACR, Melo Diniz MFF, Medeiros IA 2010. Possibilidades terapêuticas e risco toxicolgico de Jatropha gossypiifolia L: uma revisão narrativa. Rev Bras Pl Med 12: 346-357.

Mariz SR, Cerqueira GS, Araújo WC, Duarte JC, Melo AFM, Santos HB, Oliveira K, Diniz MFFM, Medeiros IA 2006. Estudo toxicológico agudo do extrato etanólico de partes aéreas de Jatropha gossypiifolia L. em ratos. Rev Bras Farmacogn 16: 372-378.

Michalany J 19898. Técnica histológica em anatomia patológica: com instruções para o cirurgião, enfermeira e citotécnico. Michalany, São Paulo.

Tomlinsom B, Chan TYK, Chan JCN, Critchley JAJH, But PPH 2000. Toxicity of complementary therapies: an eastern perspective. $J$ Clin Pharmacol 40: 451-456.

\section{*Correspondence}

\section{Saulo R. Mariz}

Centro de Ciências Biológicas e da Saúde, Universidade Federal de Campina Grande, Avenida Juvêncio Arruda, 795, Bodocongo, 58109-790 Campina Grande-PB, Brazil saulo.mariz@ufcg.edu.br Tel. +558333215921 